\title{
The Curriculum and Education System of Hong Kong Tourism Higher Education -- Taking Hong Kong Polytech University as an example
}

\author{
ZHONG lina ${ }^{1}$ \\ Beijing International Studies University, Tourism \\ Management School, Beijing, 100024, China
}

\author{
TANG Junyi ${ }^{2}$ \\ Beijing International Studies University, Tourism \\ Management School, Beijing, 100024, China
}

\begin{abstract}
Hong Kong Polytech University is the representative of tourism higher education in Hong Kong, offering various courses in hotel management and tourism management at the Doctor, Masters and Bachelor levels, whose curriculum and education system have been quite perfect. The PolyU has cultivated a large number of highquality professional people for the hotel and tourism industry. Excellent teachers, modern curriculum and the education concept of attaching great importance to the practice are the reasons why it can cultivate senior executives with international perspective, skills and social responsibility.
\end{abstract}

Keywords: Hong Kong Polytech University; tourism higher education; practical ability

\section{Introduction}

According to market research firm "Euromonitor", Hong Kong ranked first in the "global tourism city rankings ". In 2012, Hong Kong attracted over 23,700,000 visitors, among which $60 \%$ are from the mainland China. As a Special Administrative Region of the People's Republic of China, Hong Kong is enjoying its share of the country's phenomenal growth and prosperity. It has also held its position as Asia's most international city: multilingual, sophisticated, a preferred business and pleasure destination for travelers from both East and West. Where better to locate a seat of teaching and learning for the hospitality industry?

Tourism higher education, the foundation for the rapid development of tourism industry, is to cultivate highquality tourism professions. Therefore, it is very necessary to pay attention to tourism higher education in Hong Kong.

The School of Hotel and Tourism Management (SHTM) in PolyU has risen to become one of the largest hospitality and tourism schools in Asia and amongst the top such schools worldwide. With 65 academics drawing from 20 countries and regions, the School is ranked No. 2 globally based on research and scholarship, according to a study published in the Journal of Hospitality and Tourism Research in 2009. In 2012, the SHTM was bestowed the McCool Breakthrough Award by the International Council on Hotel, Restaurant, and Institutional Education (I-CHRIE) recognizing its breakthrough in the form of its teaching and research hotel - Hotel ICON - the heart of the School's innovative approach to hospitality and tourism education. Its unique work worth researching and analyzing.

\section{Literature Review}

Since 1996, China has begun to carry out the research of tourism education, which was marked by the publication of Tourism Education Supplement in Tourism Tribune. The research content mainly includes the development of tourism education, tourism discipline construction, tourism professional curriculum, teaching materials and teaching methods. The higher education of tourism started in 1978, marked by the establishment of Shanghai Institute of Tourism. In 1982, Department of economics in former Hangzhou University set up the tourism programs for bachelor degree, marking the formation of higher tourism education system in China. With the rapid development of higher tourism education, researches in this area have gradually carried out, mainly concentrating in the nature and curricula construction of tourism higher education. ${ }^{[1]}$

Different universities choose different kinds of curriculum construction. As for PolyU, it pays more attention to the professional practical ability training in undergraduate education, while doctoral education mainly focuses on research ability.

\section{Methods}

Based on the academic and curriculum system and educational pattern of tourism higher education in PolyU, mainly sorting out and analyzing information from literatures, education websites and alumni interviews, the paper aims to analyze and summarize the characteristics of its education mode and propose corresponding suggestions to domestic higher education of tourism.

\section{Academic system}

There are two priority research areas in SHTM of PolyU: Tourism Management and Hotel Management. It offers academic degree including Bachelor of Science, Master of 
Science, Master of Management and Doctor of Management.

The direction of the undergraduate degree is the Tourism Management and Hotel Management. It combines the theory and practice of business tourism with a customerservice orientation to produce graduates who can perform in a variety of tourism industry positions. Students learn to be customer-focused, analytical and independent, and at the same time develop communication and leadership skills. They also gain a global perspective to meet the growing challenges that are faced by the dynamic tourism industry.

The direction of Master degree is professional masterdirected. The aim is to develop student's knowledge and management skills in the corresponding industries through a blend of strategic perspectives and pragmatic implementations. Industry practice, management skills and research competencies will be developed through the interdisciplinary subject exposure, problem identification, decision making theory and management application, in order to adapt to the global background of the industrial environment. ${ }^{[3]}$

The objective of the $\mathrm{PhD}$ programme is to provide a theoretical and research base to prepare graduates for educational and research positions in the hotel and tourism industry. The programme offers advanced research training based on individual interests and career aspirations to allow students to develop the ability to complete significant research in a specific area of hospitality or tourism. The intellectual and supportive environment fostered by the School encourages academic staff and students to collaborate to conduct research and disseminate information through scholarly publications and conference presentations. Research areas include: Hotel and Tourism Tech Management, Tourism Management, Tourism Economy, Financial Management, Conference and Event Management, Hotel and Restaurant Management. ${ }^{[4]}$

The paper mainly overviews and analyzes the relevant tourism majors in PolyU. The other will not be listed here.

TABLE 1 The Academic System of PolyU

\begin{tabular}{cc}
\hline $\begin{array}{c}\text { Degree } \\
\text { setting }\end{array}$ & Majors \\
\hline $\begin{array}{cc}\text { Bachelo } \\
\mathbf{r}\end{array}$ & $\begin{array}{c}\text { Tourism Management } \\
\text { Hotel Management }\end{array}$ \\
\hline International Hospitality \\
Master & $\begin{array}{c}\text { Mlobal Hospitality } \\
\text { Business }\end{array}$ \\
& $\begin{array}{c}\text { International Tourism and } \\
\text { Convention Management }\end{array}$ \\
\hline Doctor & $\begin{array}{c}\text { Tourism and Hotel } \\
\text { Management }\end{array}$ \\
\hline
\end{tabular}

\section{Curriculum}

\subsection{Undergraduate curriculum}

The SHTM in PolyU offers two majors in Bachelor of Science degree: Bachelor of Science (Hons) in Hotel Management and Bachelor of Science (Hons) in Tourism Management. According to duration, each major is subdivided into two kinds of training program. The main difference is to provide students with different length, different regions and different kinds of internship and practice way.

\subsubsection{Curriculum of four years full-time undergraduates}

Students in the BSc (Hons) four years full-time programmes must complete General University Requirements. The General University Requirements includes Healthy Lifestyle, Language and Communication Requirements, Cluster Area Requirements and Common Mandatory Subjects. [2]

It's worth noting that students have to complete a subject designated as "China-related" from of the cluster areas. In 2011 , there were $28,100,000$ mainland visitors traveled to Hong Kong, with HK \$5,249 per capita consumption and HK $\$ 8,220$ from overnight visitors. At present, Chinese mainland is the biggest tourist recourses market of Hong Kong. Therefore, learning "China-related" cluster areas is a way to better understand the characteristics and requirements of the tourist market and to improve service quality of tourism destination.

In addition to learning professional skills and knowledge, four years full-time undergraduates are required to establish a correct concept of employment and make a career planning. In terms of optional course and minor course, students can take free choices from SHTM or another department/school within the University. Besides, students must take part in Work-Integrated Education (WIE) and Professional Development Course.

\subsubsection{Curriculum of three years full-time undergraduates}

The programmes run for three years, with an optional sandwich year of extended workplace training between the second and final years.

Year one introduces students to the hospitality and tourism industry, covering foundation management skills. A 10-week Work-integrated Education placement at the year's end allows them to gain hands-on experience in a hotel, tourism, food-service or related organization. In Year Two, the focus is on learning from case studies and applying knowledge to new situations. At the end of the year students can choose another 10-week Work-Integrated Education placement, or a 48-week sandwich year placement. Year Three focuses on group assignments and individual projects, allowing students to further develop 
their management skills and build on their operational experience. $^{[2]}$

\subsubsection{Brief summary of undergraduate curriculum}

Students majoring in Tourism Management and Hotel Management need to learn the general university foundation courses and professional courses series of hotel and tourism. Tourism Management majors will continue to study tourism professional knowledge, including the tourism professional theory courses, application courses, and the Career track option subject mainly to attractions and visitor management in the private sector while china tourism and urban tourism in the state sector. Hotel Management majors pay more attention to hotel operations and food and beverage management.

Tourism undergraduate education in PolyU pays great attention to students' professional practice ability. It requires students to take part in WIE and Professional Development Course, which is an effective way to apply theory in the working environment. Equipped with not only professional knowledge but also industry experience after graduation, students can be competent for a variety of positions in the tourism industry.

In comparison, three years full-time programme pays more attention to cultivate students' practical ability. Because they have to get another vocational training between the second year and third year.

\subsection{Postgraduate curriculum}

The SHTM in PolyU offers three majors in Master of Science degree: MSc in Global Hospitality Business, MSc in International Hospitality and $\mathrm{MSc}$ in International Tourism and Convention Management.

\subsubsection{Curriculum of MSc in International Hospitality, and International Tourism and Convention Management.}

Both of the two programmes offer full-time and part-time programmes to postgraduate students. The main difference lies in the duration to finish MSc and $\mathrm{PgD}$ and the class schedule. Classes for part-time students are usually scheduled in the evenings from Asian context in global background Monday to Friday, which allows students to work while going to school.

Although there are two majors divided, their curriculums are about the same. All students should study the current situation of China Hotel and Tourism Business to improve service quality and tourist satisfaction. Only a few professional subjects and management subjects are different. All courses are delivered in English, which enables students to study global tourism trends and problems, develop their international perspective and recognize the Asian context in the global background.

The aim of master programmes is to develop students' knowledge and management skills in the hospitality industry or the international tourism and convention industry through a blend of strategic perspectives and pragmatic implementation. Industry practice, management skills and research competencies will be developed through the interdisciplinary subject exposure, problem identification, decision making theory and management application. ${ }^{[3]}$

\subsubsection{Curriculum of MSc in Global Hospitality Business}

The MSc in Global Hospitality Business is a program targeting high-potential Bachelor graduates from leading hospitality universities around the world. The aim of this programme is to improve students' leadership, decision making, problem solving and research ability to adapt to the changing hotel industry environment. ${ }^{[3]}$

\subsection{Doctor curriculum}

The SHTM offers a research-based graduate programme that leads to a Doctor of Philosophy $(\mathrm{PhD})$ degree. This degree programme is designed for students who wish to pursue pure research in their advanced education.

The objective of the $\mathrm{PhD}$ programme is to provide a theoretical and research base to prepare graduates for educational and research positions in the hotel and tourism industry. ${ }^{[4]}$

PolyU is very strict with Doctoral students' academic moral requirements. The "Ethics: Research, Professional and Personal Perspectives" is the only compulsory subject. Because the university is clear about devoting to cultivate professional researchers with outstanding academic ability, noble moral character, strong social responsibility and international perspective. ${ }^{[5]}$

\section{Educational pattern}

\subsection{Work-Integrated Education}

Undergraduates in SHTM of PolyU should complete a mandatory Work-Integrated Education (WIE) component. WIE is work-based learning experience which takes place in an organizational context relevant to a student' $\mathrm{s}$ future profession. The focus is to help students develop a range of valuable generic abilities and to apply theories to real-life situations.

The WIE in SHTM mainly includes the following aspects:

A) Enterprise executives and major students recruit interview master students

B) Enterprises participate in the syllabus design together with the university

C) School host hiring activities called "one-day professor"

D) Enterprises participate in the students' internship program

E) Mentor project

F) Consultative committee

G) Teacher training ${ }^{[6]}$ 


\subsection{Soft skills training}

Besides professional skills training, soft skills training is indispensable. Scholars of tourism research should not only focus on the literature books but also strengthen their communication with the outside world and establish a good personal image showing the charm of a scholar.

In PolyU, undergraduates should learn not only learn professional knowledge but also basic courses, including healthy life style, languages, social communication and career planning. Doctors have many opportunities to participate in international conferences, which requires them to have a proper dress and etiquette, be able to write resumes and emails and communicate with other attendees.

\subsection{Teaching and research hotel}

Wholly owned by PolyU and an extension of the SHTM, Hotel ICON is the first teaching and research hotel of its kind in the world. Hotel ICON is a purpose-built hotel that completely integrates teaching, learning and research in a full-service environment. ${ }^{[7]}$

To fully integrate Hotel ICON into its curriculum, the SHTM has revamped a whole host of subjects that span daily hotel operations, event management, financial administration, entrepreneurship and service quality management, all of which include practical training. SHTM students are privileged to use Hotel ICON's many opportunities for learning as a launch pad for their dreams.

\section{Enlightenment for tourism higher education in Chinese mainland}

\subsection{Optimize curriculum system and improve students' soft skills}

Tourism higher education should pay attention not only to professional knowledge but also to soft skills. General education is a compulsory part in undergraduate education in PolyU. Undergraduates are able to communicate freely with others under the background of globalization. In addition, quality-oriented education is vital to tourism higher education. Introduction to Psychology, Introduction to Sociology, Ethics and Social Responsibility etc. are common subjects of undergraduate education SHTM of PolyU. It is also strict with students' academic moral requirements. All of these courses focus on the quality development of human being.

However, most tourism higher education in Chinese mainland mainly pay attention to deliver professional knowledge and ignore the soft skills training. As a result, many students, though equipped with abundant professional knowledge, even don't know how to behave in society. ${ }^{[8]}$

Tourism higher education plays an important role in cultivating high-quality tourism professionals. As curriculum is the core of education, China must optimize its traditional curriculum system by adding general education courses and quality-oriented education to improve students' soft skills.

\subsection{Improve the operation mode of Work-Integrated Education}

Higher education of tourism in Hong Kong pays much attention to the practical ability of students, whose WIE is widely recognized by all walks of life. Undergraduates in SHTM must join the WIE placement and the school also invites industry insiders to deliver lectures regularly about the latest tourism industry trends.

With the transformation and upgrading of the tourism industry and intense competition, tourism higher education becomes more and more important. However, there is a big gap between the real market demand and current curriculum system in Chinese mainland.

\section{CONCLUSIONS}

Although some universities with tourism majors in Chinese mainland have cooperation with enterprises, the effectiveness is not significant as PolyU. We should learn from it and improve the operation mode of WIE. ${ }^{[9]}$ Possibly we could also set up a teaching and research hotel in university and provide students with more internship opportunities in the tourism industry.

\section{References}

[1] Qiu M, "A Summary of Research on China's Tourism Education," Tourism Tribune, S1. 173-176, 2003.

[2] http://hotelschool.shtm.polyu.edu.hk/eng/academic/pro grams_overview.jsp?ID=23\&SA=posthk\&Tag=1\&Prog ram $=$ bsc $\&$ SubProg $=\mathrm{hm}$

[3] http://hotelschool.shtm.polyu.edu.hk/eng/academic/pro grams_overview.jsp?ID=42\&Tag=1\&Program=pgd\&S ubProg $=$ msc $\&$ SA $=$ posthk

[4] http://hotelschool.shtm.polyu.edu.hk/eng/academic/pro grams_overview.jsp?ID=9\&SA=posthk \&Tag=1\&Progr am $=$ phd \&SubProg

[5] Luo J, "Tourism Ph.D.: Reserves what for the future?" Tourism Tribune, 02. 13-15, 2014.

[6] Wang Y, "Employment attitude of students majoring tourism-enlightenment of investigation and training in the Hong Kong Polytechnic University," Tourism Overview, 08. 241-242, 2013.

[7] http://hotelschool.shtm.polyu.edu.hk/eng/school/shtm_h otel_icon.html

[8] Duan W, "Enlightenment from foreign tourism education to domestic tourism professional education," High School Years, 06. 134-135, 2012.

[9] Zhang D, "A Study on the Course System and Teaching Methods of Tourism Management (Undergraduate Course)," Tourism Science, 02. 41-43, 2001. 